\title{
Rancang Bangun Mesin Pemotong Pipa Dengan Pergerakan Torch Otomatis Untuk Optimasi Proses Plasma Cutting
}

\author{
Pujono $^{1}$, Anggun Pamuji ${ }^{2}$ \\ Jurusan Teknik Mesin, Politeknik Negeri Cilacap, Indonesia \\ email : ${ }^{1}$ poejono07@gmail.com, ${ }^{2}$ anggunpamuji312@gmail.com
}

\begin{abstract}
ABSTRAK
Perkembangan dunia industri yang semakin meningkat membuat proses produksi dalam suatu industri atau pabrik membutuhkan teknologi yang semakin berkembang dan bahan-bahan serta alat-alat yang mudah untuk didapatkan agar proses produksi dapat berjalan dengan lancar. Salah satu komponen yang dibutuhkan dalam dunia industri adalah material dengan bentuk pipa. Beberapa industri masih melakukan proses pemotongan pipa menggunakan las oxy acetylene yang masih menggunakan tangan dan mesin gergaji potong. Hal tersebut tentunya kurang efektif karena pipa memiliki ukuran dan ketebalan yang berbeda. Pemotongan pipa menggunakan las oxy acetylene akan menghasilkan potongan yang kurang rapih karena prosesnya masih manual menggunakan tangan dan harus memutar pipanya, sehingga dibutuhkan suatu alat untuk mempermudah dalam proses pemotongan tersebut. Mesin pemotong pipa menggunakan plasma cutting adalah mesin yang dibuat untuk memudahkan proses pemotongan pipa. Proses kerja pemotongan pipa yaitu alat pemotongnya yang bergerak memutar untuk menghasilkan potongan pipa. Dengan adanya mesin ini dapat membantu mempercepat mahasiswa dalam proses pemotongan pipa tanpa harus memutar pipa yang akan dipotong. Tujuan dari rancang bangun rangka pada mesin pemotong pipa menggunakan plasma cutting ini yaitu menghitung bagian-bagian elemen mesin, menentukan rangka mesin, menentukan rancangan konsep mesin dan membuat desain drawing mesin. Dalam pembuatan mesin ini penulis menggunakan pendekatan metode perancangan dari VDI 2222, software gambar menggunakan Solidworks dan gambar kerja menggunakan standar ISO 1101 : 1983. Hasil keputusan evaluasi rancangan konsep yaitu, rangka menggunakan besi hollow 40 × 40 × 3mm dengan estimasi waktu produksi yang digunakan adalah selama 15,32 jam atau sama dengan 2 hari kerja jika dalam 1 hari dikerjakan selama 8 jam. Kemudian bill of material dalam pembuatan rangka pada mesin ini menghabiskan sebanyak 53 part. Hasil pemotongan terbaik didapatkan dari pemotongan pipa tebal $8 \mathrm{~mm}$ dengan kecepatan $10 \mathrm{rpm}$. Sehingga dari perencanaan tersebut, rangka pada mesin pemotong pipa menggunakan plasma cutting, dapat berfungsi dengan baik. sehingga dibutuhkan suatu alat untuk mempermudah dalam proses pemotongan tersebut.
\end{abstract}

Kata kunci: perancangan, plasma cutting, pipa

\begin{abstract}
The development of the industrial world that is increasingly making the production process in an industry or factory requires increasingly developing technology and materials and tools that are easy to obtain so that the production process can run smoothly. One component needed in the industrial world is a material in the form of a pipe. Some industries still do the pipe cutting process using oxy acetylene welding which still uses hand and saw saws. This is certainly not effective because the pipes have different size and thickness. To cut the pipe using oxy acetylene welding will produce less neat pieces because the process is still manual by hand and must rotate the pipe, so we need a tool to facilitate the cutting process. Pipe cutting machine using plasma cutting is a machine made to facilitate the pipe cutting process. The process of cutting pipes is cutting tools that move around to produce pieces of pipe. With this machine, it can help speed up students in the process of cutting pipes without having to rotate the pipe to be cut. The purpose of the skeletal design of the pipe cutting machine using plasma cutting is to count the elements of the machine, determine the frame of the machine, determine the design concept of the machine and make the design of the draw frame. In making this machine the author uses the design method approach of VDI 222, drawing software using Solidworks 2017 and working drawings using ISO standards. The results of the concept design evaluation decision are, the framework uses $40 \times 40 \times 3 \mathrm{~mm}$ hollow iron with an estimated production time used is 15.32 hours or equal to 2 working days if it is done in 1 day for 8 hours. Then the bill of material in making the frame on this machine spent 53 parts. The best cutting results are obtained from cutting 8 $\mathrm{mm}$ thick pipes with a speed of $10 \mathrm{rpm}$. So from the planning, the framework on the pipe cutting machine using plasma cutting, can function properly. so we need a tool to facilitate the cutting process.
\end{abstract}

Keywords: design, plasma cutting, pipe 


\section{Pendahuluan}

Teknologi industri mengalami perkembangan yang pesat khususnya di Indonesia. Pada era sekarang ini, manusia dituntut untuk bekerja secara cepat dan tepat. Perkembangan dunia industri yang semakin meningkat membuat proses produksi dalam suatu industri atau pabrik membutuhkan teknologi yang semakin berkembang. Selain dunia industri, dunia Pendidikanpun membutuhkan teknologi sebagai sarana penunjang agar terlaksananya kegiatan teori maupun praktek. Salah satu proses di industri manufaktur atau praktek di kampus khususnya pada jurusan manufaktur/teknik mesin adalah proses pemotongan pipa dengan diameter yang cukup besar, minimal 4 inch. Proses pemotongan pipa dengan diameter minimal 4 inch atau yang lebih kecil biasanya menggunakan las oxy acetylene atau mesin gergaji [1], [2]. Hal tersebut tentunya kurang efektif karena faktanya pipa memiliki ukuran dan ketebalan yang berbeda. Untuk pemotongan pipa menggunakan las oxy acetylene akan menghasilkan potongan yang kurang rapih karena prosesnya masih manual menggunakan tangan dan harus memutar pipanya. Pemotongan menggunakan gergaji potong hanya efektif digunakan untuk pipa dengan ketebalan dan diameter kecil, karena untuk pipa yang memiliki diameter dan ketebalan yang besar akan memakan waktu cukup lama dan juga konsumsi listrik yang lebih banyak, sehingga dibutuhkan suatu alat untuk mempermudah dalam proses pemotongan tersebut.

Mesin pemotong pipa menggunakan plasma cutting adalah mesin yang dibuat bertujuan untuk memudahkan dalam proses pemotongan pipa tersebut [3]. Cara kerja mesin ini yaitu alat pemotongnya yang berputar mengelilingi pipa. Pemotongan yang dihasilkan akan lebih rapih dan dapat mengurangi proses finishing sehingga dapat membantu proses pemotongan pipa. Proses pembuatan mesin pemotong pipa menggunakan plasma cutting diawali dengan melakukan proses perancangan. Perancangan merupakan suatu kegiatan awal dari suatu rangkaian kegiatan dalam proses pembuatan produk, dalam pembuatan produk sangat diperlukan suatu gambaran yang digunakan untuk dasar-dasar dalam melangkah atau bekerja. Gambaran metode perancangan VDI 2222 dapat disajikan dalam bentuk diagram alir sebagai metode dalam perencanaan dan perancangan. Metode VDI 2222 dilakukan melalui tahapan perencanaan, mengkonsep, merancang dan implementasi penyelesaian hasil perancangan.

Berdasarkan permasalahan yang ada mengenai proses produksi mesin pemotong pipa menggunakan plasma cutting, alat ini memiliki tujuan membuat desain wujud dan desain detail dari rangka mesin pemotong pipa menggunakan plasma cutting. Tujuan lainnya adalah menghitung mekanika teknik pada rangka mesin pemotong pipa menggunakan plasma cutting dan estimasi waktu produksi rangka mesin pemotong pipa menggunakan plasma cutting. Selain itu, tujuan berikutnya adalah menentukan bill of material dan pengujian komponen pada rangka mesin pemotong pipa menggunakan plasma cutting.

\section{Penelitian Terkait}

Tsyafaruddin Siregar, Aan Sukandar (2011) [4] telah membuat suatu disain struktur rangka pada mesin penggilingan adonan pangsit kapasitas $80 \mathrm{~kg} / \mathrm{jam}$ untuk home industry . Pada perencanaan elastis, tegangan yang diijinkan harus dikalikan dengan faktor keamanan yang nilainya $\mathrm{fk}=1,5$, dimana hasilnya merupakan batas tegangan yang tidak boleh dilewati oleh tegangan yang terjadi. Berdasarkan hasil perhitungan pada perancangan mesin penggiling adonan pangsit dengan memperhatikan berbagai ketentuan maka dapat diambil kesimpulan untuk rangka adalah bahan baja ST 37 dengan dimensi profil siku 25 x 25 x 5 mm dan untuk saluran pengeluaran bahan baja St 37 dengan dimensi plat 650 x 492 x $42 \mathrm{~mm}$.

Sutikno, Endi (2011) [5] telah melakukan analisa pada state loading carbody $\mathrm{TeC}$ railbus saat penarikan oher lokomotif ketika railbus tidak dioperasikan dari simulasi, pada distribusi muatan statis dan hasil dari stres yang terjadi pada ketiga kasus, yaitu nilai stres terbesar dalam kasus pertama terjadi di daerah dengan bagian nilai tegangan 157,883 MPa, dalam kasus kedua terjadi di sebuah frontpart area dengan nilai tegangan 193.033 MPa, dan yang ketiga, tekanan 140.615 MPa terjadi di area crossbeam underframe. Stress ketiga terjadi pada ketiga kasus yang tersisa pada batas kekuatan material, sehingga dapat disimpulkan $\mathrm{TeC}$ railbus adalah desain konstruksi carbody mempertimbangkan mampu menerima beban yang akan diterima railbus selama operasi.

Ahmad RK., dkk. (2018) [6] Seiring dengan perkembangan teknologi, logam dapat didaur ulang, dipotong dan disambung dengan mudah. Beberapa perusahaan asing maupun lokal telah membuktikan hal ini dengan menciptakan mesin-mesin produksi berskala besar yang dapat mengolah bahan logam dengan cukup mudah khususnya baja. Dengan memproduksi mesin yang mampu bekerja dengan skala besar inilah sehingga mesin-mesin yang berskala kecil tidak terlalu diutamakan mengingat keuntungannya yang lebih sedikit. Salah satu contoh mesin yang berskala kecil adalah mesin cutting plasma. Desain sistem mekanik plasma cutter menggunakan prinsip run stabilizer process adalah suatu desain mesin penstabil yang diperuntukan untuk plasma cutter dalam menunjang proses pemotongan plat logam dengan ketebalan kurang 
dari $15 \mathrm{~mm}$. Plasma cutter adalah suatu komponen dari seperangkat mesin cutting plasma yang berguna untuk menyemburkan nyala api plasma untuk proses pemotongan, sementara proses operasionalnya masih sebagian besar dikendalikan oleh operator. Karena beberapa aspek masih dikendalikan oleh operator berupa ketinggian antar torch dan benda kerja, kecepatan pemotongan, sudut pemotongan serta kelurusan pemotongan maka untuk hasil pemotongan yang rapi dan presisi sulit untuk dicapai. Pada penelitian ini didesain suatu mesin penstabil plasma cutter yang dapat mengoptimalkan kualitas hasil potongan dari proses pemotongan cutting plasma. Desain mesin ini sendiri memiliki 3 bagian utama yaitu lengan pengatur titik potongan, badan mesin dan rel mesin. Mesin ini menggunakan 4 susun planetary gearset dengan rasio total adalah $1: 2210.8615$ sebagai pereduksi putaran motor dc guna meningkatkan torsi mesin dalam menjaga kestabilan pemotongan. Jarak tempuh mesin yang didapatkan adalah $361.1 \mathrm{~mm} /$ menit dengan kecepatan pemotongan yaitu $6.01 \mathrm{~mm} / \mathrm{s}$.

\section{Metodologi}

Dalam menyelesaikan penelitian ini, metode yang dilakukan adalah pengamatan lapangan terhadap pembuatan rangka dan ragum untuk plasma cutting, melakukan rancang bangun dengan metode perancangan menurut VDI 2222 dan dilakukan kajian pustaka sebagai bahan pertimbangan untuk melihat kemungkinan dilakukan perbaikan-perbaikan [7], [8].

Metodologi perancangan menurut VDI 2222 memuat tahapan-tahapan sebagai berikut:

a) Perencanaan:

Merencanakan desain yang akan dibuat berdasarkan tuntutan masyarakat/konsumen/ marketing. Tahap ini berisi tentang masukan desain dan rencana realisasi desain tersebut. Tahapan ini akan diperoleh input desain dan rencana desain.

\section{b) Mengkonsep:}

Memberikan sketsa dan spesifikasi teknis terhadap ide desain yang sudah ditetapkan.

\section{c) Merancang:}

Memberikan desain wujud dan desain rinci terhadap ide desain. Ide ini sudah melewati analisa, pemilihan dan penentuan ide desain.

\section{d) Penyelesaian:}

Melakukan finishing terhadap rancangan desain, dengan melakukan verifikasi terhadap tuntutan desain dari masyarakat/konsumen/marketing yang sudah diberikan pada tahap perencanaan dan menyiapkan dokumen untuk disampaikan kepada lini produksi. Jika hasil desain tidak sesuai dengan tuntutan masyarakat, maka akan dilakukan tahapan perencanaan desain kembali.

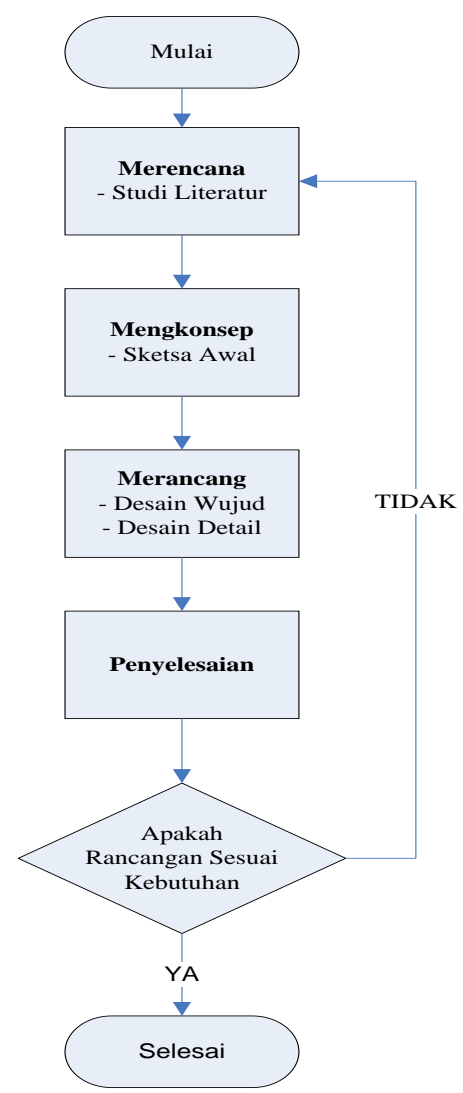

Gambar 1. Diagram alir perancangan VDI 2222.

\section{Hasil Dan Pembahasan}

\subsection{Merencana}

Salah satu upaya yang dapat dilakukan untuk mempermudah pada saat proses Pemotongan pipa, penggunaan hasil dari produksi ini adalah pemotongan pipa, sehingga untuk menambah produktifitas dan peningkatan kualitas dari hasil potongan pipa kepada masyarakat, maka penulis bermaksud untuk merancang suatu alat yaitu plasma cutting. Dengan adanya plasma cutting tersebut diharapkan menambah produktifitas dan kualitas pemotongan pipa dan pemotongan pipa akan lebih mudah.

\subsection{Input desain}

Hasil input desain dari masyarakat dapat dirangkum dalam daftar kebutuhan dari plasma cutting yang akan digunakan sebagai acuan pembuatan plasma cutting tersebut seperti pada Tabel 1.

\section{Tabel 1. Daftar kebutuhan}

\begin{aligned} & \hline No \multicolumn{1}{c}{ Kebutuhan Mesin } \\ & \hline 1 Dapat memotong pipa dengan baik. \\ & 2 Dapat mempercepat proses pemotongan pipa. \\ & 3 Memiliki bentuk mesin yang sederhana. \\ & 4 Perawatan dan pemeliharaan mesin mudah \\ & dan murah. \\ & 5 Proses pengoprasian mesin mudah. \\ & \hline\end{aligned}




\subsection{Realisasi desain}

Setelah spesifikasi kebutuhan dari mesin diperoleh, maka disusun rencana realisasi desain sebagai acuan dalam pembuatan mesin. Rencana realisasi desain dilihat seperti pada Tabel 2.

Tabel 2. Spesifikasi desain

\begin{tabular}{|c|c|c|}
\hline No & $\begin{array}{l}\text { Spesifikasi } \\
\text { Mesin }\end{array}$ & $\begin{array}{c}\text { Rencana Realisasi } \\
\text { Desain }\end{array}$ \\
\hline 1 & $\begin{array}{l}\text { Mesin plasma } \\
\text { cutting }\end{array}$ & $\begin{array}{l}\text { Pemahaman dalam proses } \\
\text { pembuatan plasma cutting }\end{array}$ \\
\hline 2 & $\begin{array}{l}\text { Bentuk mesin } \\
\text { sederhana }\end{array}$ & $\begin{array}{l}\text { Dibuat dengan ukuran yang } \\
\text { sesuai dengan kebutuhan }\end{array}$ \\
\hline 3 & $\begin{array}{l}\text { Perawatan dan } \\
\text { pemeliharaan } \\
\text { mesin mudah } \\
\text { dan murah }\end{array}$ & $\begin{array}{l}\text { Menggunakan komponen } \\
\text { yang mudah di dapat di } \\
\text { pasaran dan dengan harga } \\
\text { yang terjangkau }\end{array}$ \\
\hline 4 & $\begin{array}{l}\text { Pengoprasian } \\
\text { mesin mudah }\end{array}$ & $\begin{array}{l}\text { Pada plasma cutting di buat } \\
\text { sesuai dengan kapasitas, } \\
\text { mesin menggunakan tombol } \\
\text { on/off }\end{array}$ \\
\hline
\end{tabular}

\subsection{Perencanaan Bagian Mesin Pemutar Pipa}

Pada tahap ini merupakan kelanjutan setelah rencana desain tersusun dengan mempertimbangkan beberapa bagian-bagian pada mesin yang akan digunakan. Berikut ini merupakan tahapan mengkonsep plasma cutting. Sketsa awal berdasarkan hasil spesifikasi maka perlu adanya sketsa awal sebagai gambaran dalam peroses pembuatan desain.

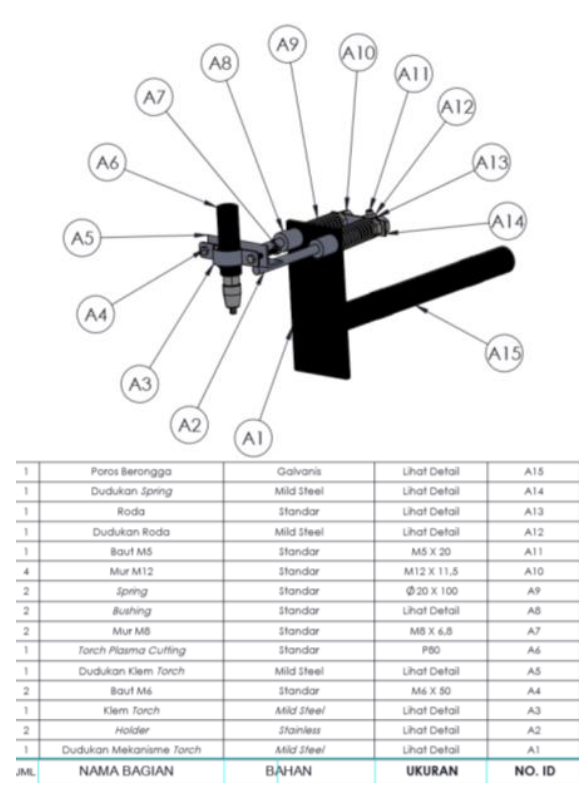

Gambar 2. Sketsa torch plasma cutting

Desain wujud dan komponen dibuat setelah menentukan konsep yang digunakan dalam mesin, berikut merupakan hasil desain wujud. Desain wujud plasma cutting dapat dilihat seperti pada Gambar 3.

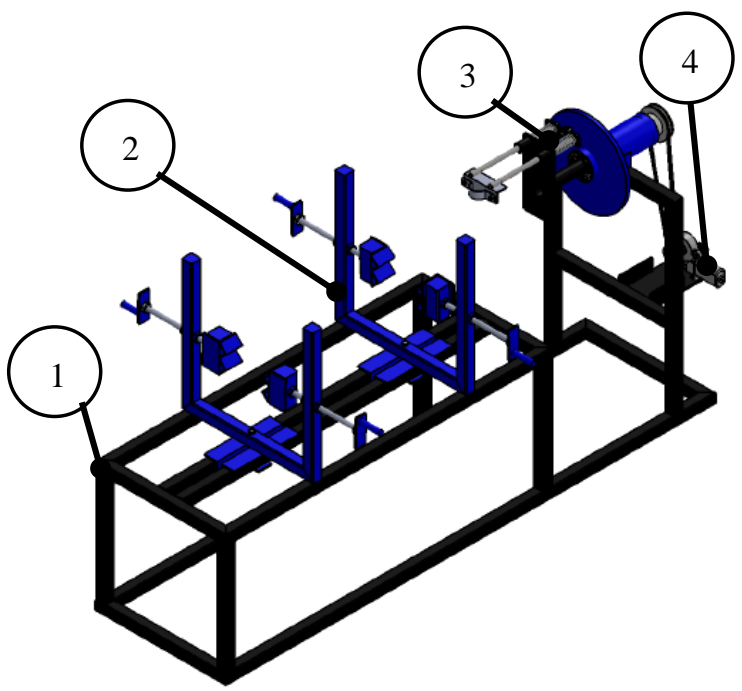

Gambar 3. Desain wujud plasma cutting

1 = Rangka Utama

2 = Ragum

3 = Dudukan Torch

4 = Dudukan Motor Penggerak

\subsection{Perhitungan mekanika teknik rangka.}

Sesuai asumsi awal beban yang dikenakan merupakan beban merata.

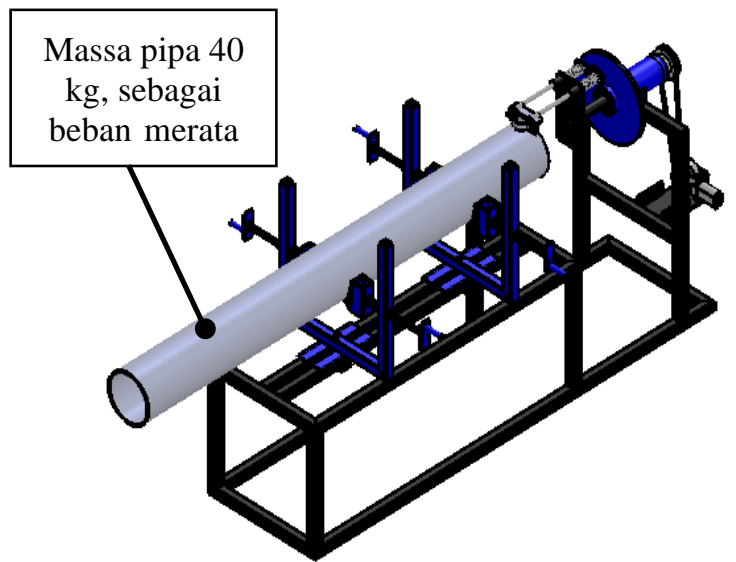

Gambar 4. Pembebanan plasma cutting

\subsection{Perhitungan mekanika teknik rangka}

Diketahui massa pipa yang akan dipotong (m) adalah $40 \mathrm{~kg}$ sehingga gaya yang bekerja pada rangka ragum dapat dicari dengan persamaan berikut.

$$
\begin{aligned}
& \mathrm{F}=\mathrm{m} \cdot \mathrm{g} ; \text { Dimana: } \\
& \mathrm{F}=\text { gaya }(\mathrm{N}) \\
& \mathrm{m}=\text { massa benda }(\mathrm{kg}) \\
& \mathrm{g}=\text { percepatan gravitasi }\left(10 \mathrm{~m} / \mathrm{s}^{2}\right)
\end{aligned}
$$


Sehingga gaya yang bekerja dapat dicari dengan persamaan sebagai berikut.

$$
\begin{aligned}
\mathrm{F} & =\mathrm{m} \cdot \mathrm{g} \\
& =40 \times 10 \\
& =400 \mathrm{~N}
\end{aligned}
$$

Karena ada 4 tumpuan maka beban dibagi empat di tiap tumpuan menjadi $100 \mathrm{~N}$.

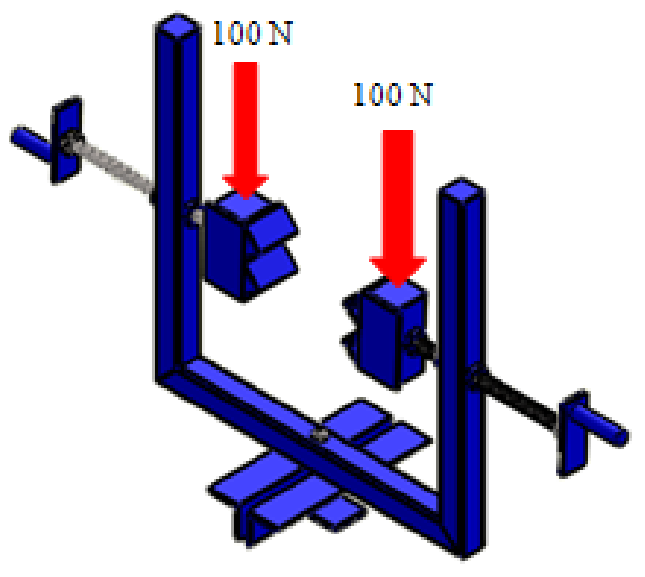

Gambar 5. Posisi pembebanan pada ragum

\subsection{Perencanaan diameter poros ulir pada ragum}

Perhitungan momen puntir rencana $(\mathrm{T})$, diketahui beban yang akan diterima oleh poros berulir adalah sebesar $100 \mathrm{~N}$ dan jari-jari pegangan pemutar ke poros adalah $25 \mathrm{~mm}$.

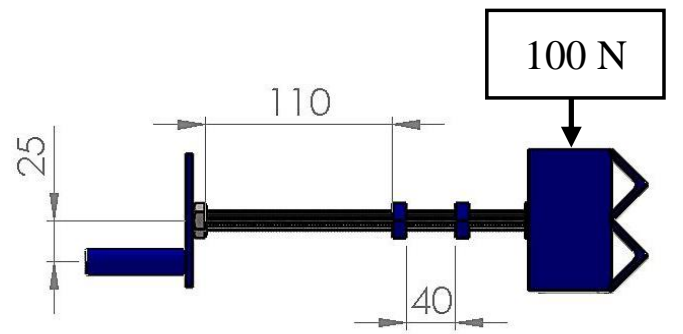

Gambar 6. Pengunci pipa pada ragum

Jadi untuk menghitung momen puntir rencana dapat dicari dengan persamaan berikut.

$\mathrm{T}=\mathrm{F} \times \mathrm{r}$;

Dimana :

$\mathrm{T}=$ Momen puntir (Kg.mm)

$\mathrm{F}=$ Gaya $(\mathrm{N})$

$\mathrm{r}=$ Jari-jari (mm)

Sehingga momen puntir rencana dapat dicari dengan persamaan berikut.

$$
\begin{aligned}
& \mathrm{T}=\mathrm{F} \times \mathrm{r} \\
& \mathrm{T}=100 \times 25 \\
& \mathrm{~T}=2500 \mathrm{~N} . \mathrm{mm} \\
& \mathrm{T}=250 \mathrm{Kg} \cdot \mathrm{mm}
\end{aligned}
$$

\subsection{Perhitungan tegangan geser izin $\left(\tau_{a}\right)$}

Diasumsikan material yang digunakan adalah poros batang baja ST-37 dengan spesifikasi : kekuatan tarik $\left(\sigma_{\mathrm{B}}\right)=37 \mathrm{~kg} / \mathrm{mm}^{2}$, faktor keamanan $\left(\mathrm{Sf}_{1}\right)=5,6$, konsentrasi tegangan $\left(\mathrm{Sf}_{2}\right)=2,5$, jadi untuk menghitung tegangan geser dapat menggunakan persamaan sebagai berikut :

$\tau_{\mathrm{a}}=\frac{\sigma_{\mathrm{B}}}{\left(\mathrm{Sf}_{1} \times \mathrm{Sf}_{2}\right)}$;

Dimana:

$\tau_{\mathrm{a}}=$ tegangan geser $(\mathrm{kg} / \mathrm{mm} 2)$

$\sigma_{\mathrm{B}}=$ kekuatan tarik $(\mathrm{kg} / \mathrm{mm} 2)$

$\mathrm{Sf}_{1}=$ faktor keamanan

$\mathrm{Sf}_{2}=$ konsentrasi tegangan

Sehingga tegangan geser dapat dicari dari persamaan $\tau_{\mathrm{a}}=\frac{\sigma_{\mathrm{B}}}{\left(\mathrm{Sf}_{1} \times \mathrm{Sf}_{2}\right)}$

$\tau_{\mathrm{a}}=\frac{\sigma_{\mathrm{B}}}{\left(\mathrm{Sf}_{1} \times \mathrm{Sf}_{2}\right)}$

$\tau_{\mathrm{a}}=\frac{37}{(5,6 \times 2,5)}$

$\tau_{\mathrm{a}}=2,64 \mathrm{~kg} / \mathrm{mm}^{2}$

\subsection{Perhitungan besarnya momen yang bekerja pada poros}

Menghitung gaya reaksi pada RA dan RB. Dimana :

$\mathrm{P} 1=100 \mathrm{~N}$

$l 1$ = Jarak ujung poros kiri ke tumpuan A $(110 \mathrm{~mm})$

$l 2$ = Jarak antara tumpuan A ke tumpuan B $(40 \mathrm{~mm})$

l3 = Jarak antara tumpuan B dengan titik pembebanan

P1 (50 mm)

Sehingga mencari besarnya gaya reaksi RA dan RB dapat dihitung dengan langkah-langkah sebagai berikut:

$$
\begin{aligned}
\Sigma \mathrm{M} & =0 \\
\Sigma \mathrm{MA} & =0 \circlearrowright(+) \\
& =-\mathrm{RB} \times l_{2}+\mathrm{P}_{1} \times\left(l_{2}+l_{3}\right) \\
& =-\mathrm{RB} \times 40+100(40 \times 50) \\
& =-40 \mathrm{RB}+9000 \\
\mathrm{RB} & =225 \mathrm{~N} \uparrow
\end{aligned}
$$

Jadi gaya reaksi pada $\mathrm{RB}=225 \mathrm{~N}$ arah gaya ke atas. Mencari gaya reaksi RA dapat dihitung dengan persamaan berikut :

$$
\begin{aligned}
\Sigma \mathrm{MB} & =0 \circlearrowright(+) \\
& =\mathrm{RA} \times l_{2}+\mathrm{P} 1 \times l_{3} \\
& =\mathrm{RA} \times 40+100 \times 50 \\
& =40 \mathrm{RA}+5000 \\
\mathrm{RA} & =-125 \mathrm{~N} \downarrow
\end{aligned}
$$

Jadi gaya reaksi pada $\mathrm{RA}=125 \mathrm{~N}$ arah gaya ke bawah. Mencari momen dititik A

$$
\begin{aligned}
\mathrm{MA} & =\mathrm{RA} \times l \mathrm{~A} \\
& =-125 \times 0 \\
\mathrm{MA} & =0
\end{aligned}
$$

Jadi momen di titik A adalah 0. Mencari momen dititik B

$$
\begin{aligned}
\mathrm{MB} & =\mathrm{P} 1 \times l_{3} \\
& =100 \times 50 \\
& =5000 \mathrm{~N} . \mathrm{mm}
\end{aligned}
$$


Jadi momen di titik B adalah 5000 N.mm, Sehingga momen lentur terbesar yang membebani poros adalah 5000 N.mm atau 500 Kg.mm.

\subsection{Perhitungan diameter poros $\left(d_{s}\right)$}

Poros yang digunakan pada bagian ini adalah poros beban puntir dan lentur dengan :

1. Faktor koreksi momen puntir $\left(\mathrm{K}_{\mathrm{t}}\right)=1$

2. Faktor koreksi momen lentur $\left(\mathrm{K}_{\mathrm{m}}\right)=1,5$

3. Momen lentur ekivalen $(\mathrm{M})=500 \mathrm{Kg} \cdot \mathrm{mm}$

4. Momen puntir rencana $(\mathrm{T})=250 \mathrm{~kg} . \mathrm{mm}$

5. Tegangan geser $\left(\tau_{a}\right)=2,64 \mathrm{~kg} / \mathrm{mm}^{2}$

Jadi untuk menghitung diameter poros bagian ini dapat menggunakan persamaan sebagai berikut :

$d_{s} \geq\left[\frac{5.1}{\tau_{a}} \sqrt{(K m . M)^{2}+(K t . T)^{2}}\right]^{1 / 3}$

Dimana :

$d_{s}=$ diameter poros $(\mathrm{mm})$

$\tau_{a}=$ tegangan geser yang diijinkan $\left(\mathrm{kg} / \mathrm{mm}^{2}\right)$

$K_{t}=$ faktor koreksi momen putir

$K_{m}=$ faktor koreksi momen lentur

$\mathrm{M}=$ momen lentur ekivalen (kg.mm)

$\mathrm{T}=$ momen puntir rencana $(\mathrm{kg} \cdot \mathrm{mm})$

Sehingga diameter poros dapat dicari dari persamaan berikut :

$d_{s} \geq\left[\frac{5.1}{\tau_{a}} \sqrt{(K m \cdot M)^{2}+(K t . T)^{2}}\right]^{\frac{1}{3}} d_{s} \geq$

$\left[\frac{5.1}{2,64} \sqrt{(1,5 \times 500)^{2}+(1 \times 250)^{2}}\right]^{\frac{1}{3}}$

$d_{s} \geq\left[1,93 \sqrt{(750)^{2}+(250)^{2}}\right]^{\frac{1}{3}}$

$d_{s} \geq[1,93 \sqrt{562500+62500}]^{\frac{1}{3}}$

$d_{s} \geq[1,93(790,57)]^{\frac{1}{3}}$

$d_{s} \geq[1525,8]^{\frac{1}{3}}$

$d_{s} \geq 11,51 \mathrm{~mm}$

Jadi diameter poros minimal yang digunakan adalah sebesar 11,51 mm.

\subsection{Perencanaan rangka}

Diketahui massa pipa yang akan dipotong (m) adalah $40 \mathrm{~kg}$, sehingga gaya yang bekerja pada rangka tengah dapat dicari dengan persamaan berikut.

$\mathrm{F}=\mathrm{m} \cdot \mathrm{g}$

Dimana :

$\mathrm{F}=$ gaya $(\mathrm{N}) ; \mathrm{m}=$ massa benda $(\mathrm{kg})$

$\mathrm{g}=$ percepatan gravitasi $\left(10 \mathrm{~m} / \mathrm{s}^{2}\right)$

Sehingga gaya yang bekerja adalah:

$\mathrm{F}=\mathrm{m} \cdot \mathrm{g}=40 \times 10=400 \mathrm{~N}$
Karena ada 2 tumpuan maka beban dibagi dua di tiap tumpuan menjadi $200 \mathrm{~N}$.

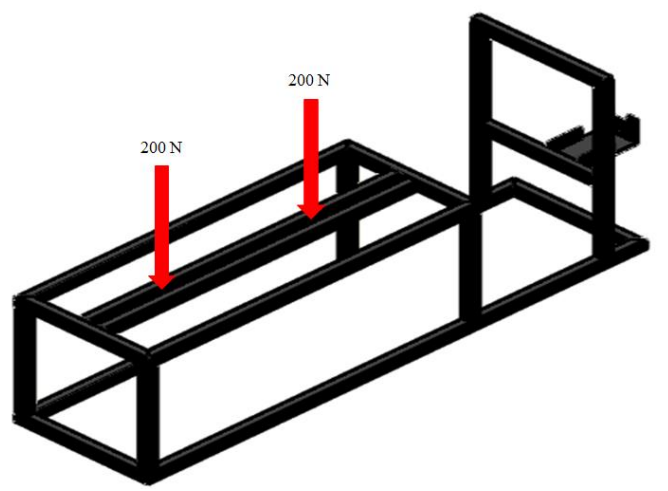

Gambar 7. Beban rangka

Menghitung gaya reaksi pada RA dan RB. Dimana:

$\mathrm{W} 1=\mathrm{W}_{2}(200 \mathrm{~N}), \mathrm{Q}_{1}=\mathrm{Q}_{2}=1 \mathrm{~N} / \mathrm{mm}$

$l 1$ = Jarak bantalan A dengan titik pembebanan pertama (200 mm)

$l 2=$ Panjang pembebanan merata pertama $(200 \mathrm{~mm})$

$13=$ Jarak antara beban merata $(200 \mathrm{~mm})$

$l 4=$ Panjang pembebanan merata kedua $(200 \mathrm{~mm})$

$15=$ Jarak titik pembebanan kedua dengan bantalan B

(200 mm)

Mencari besarnya gaya reaksi RA dan RB dapat dihitung dengan langkah-langkah sebagai berikut :

$$
\begin{aligned}
& \begin{array}{rl}
\Sigma \mathrm{M}= & 0 \\
\Sigma \mathrm{MA}= & 0 \circlearrowright(+) \\
= & \mathrm{Q} 1 \times l 2\left(l 1+\frac{l_{2}}{2}\right)+\mathrm{Q} 2 \times l 4\left(l 1+l 2+l 3+\frac{l_{4}}{2}\right)- \\
\mathrm{RB} \times l & l 1+l 2+l 3+l 4+l 5 \\
= & 1 \times 200\left(200+\frac{200}{2}\right)+1 \times 200(200+200+200 \\
\left.+\frac{200}{2}\right)= & \mathrm{RB} \times \\
& 200+200+200+200+200 \\
= & 200(300)+200(700)-1000 \mathrm{RB} \\
= & 60000+140000-1000 \mathrm{RB} \\
= & 200 \mathrm{~N} \uparrow
\end{array}
\end{aligned}
$$

Jadi gaya reaksi pada $\mathrm{RB}=200 \mathrm{~N}$ arah gaya ke atas.

$$
\begin{aligned}
\begin{aligned}
\Sigma \mathrm{MB} & =0 \circlearrowright(+) \\
& =-\mathrm{Q} 2 \times l 4\left(l 5+\frac{l_{4}}{2}\right)-\mathrm{Q} 1 \times l 2\left(l 3+l 2+l 1+\frac{l_{4}}{2}\right)+ \\
\mathrm{RA} \times & l 1+l 2+l 3+l 4+l 5 \\
& =-1 \times 200\left(200+\frac{200}{2}\right)-1 \times 200(200+200+ \\
200+ & \left.\frac{200}{2}\right)+\mathrm{RA} \times \\
& 200+200+200+200+200 \\
= & -200(300)-200(700)+1000 \mathrm{RA} \\
= & -60000-140000+1000 \mathrm{RA} \\
\mathrm{RA} & =200 \mathrm{~N} \uparrow
\end{aligned}
\end{aligned}
$$

Jadi gaya reaksi pada $\mathrm{RA}=200 \mathrm{~N}$ arah gaya ke atas. Mencari momen di titik A 


$$
\begin{aligned}
\mathrm{MA} & =\mathrm{Q} 1 \times l 2\left(l 1+\frac{l_{2}}{2}\right) \\
& =1 \times 200\left(200+\frac{200}{2}\right) \\
& =60000 \mathrm{~N} . \mathrm{mm}
\end{aligned}
$$

Jadi momen di titik A adalah 60000 N.mm. Mencari momen di titik B

$$
\begin{aligned}
\mathrm{MB} & =\mathrm{Q} 2 \times l 4\left(l 5+\frac{l_{4}}{2}\right) \\
& =1 \times 200\left(200+\frac{200}{2}\right) \\
& =60000 \text { N.mm }
\end{aligned}
$$

Jadi momen di titik B adalah 60000 N.mm, sehingga momen terbesarnya adalah 60000 N.mm

\section{Momen inersia $\left(\mathrm{I}_{\mathrm{o}}\right)$}

Besi yang dipilih adalah besi hollow dengan ukuran 40x40x3 mm.

$$
\mathrm{C}=\frac{\Sigma \mathrm{Ay}}{\Sigma \mathrm{A}}=\frac{12348}{444}=27,81
$$

Jarak dari bawah. Untuk luas keseluruhan $\left(\mathrm{I}_{\mathrm{o}}\right)$

$$
\begin{aligned}
\mathrm{I}_{\mathrm{o}}= & \frac{\mathrm{bh}^{3}}{12}=\frac{40(40)^{3}}{12} \\
= & 213333,33 \mathrm{~mm}^{4} \\
\mathrm{Ad}_{1} & =\mathrm{A}_{1} \times\left(\mathrm{y}_{1}-\mathrm{C}\right)^{2} \\
& =1600 \times(20-27,81)^{2} \\
& =1600 \times 60,99 \\
& =97593,76 \mathrm{~mm}^{4} \\
\mathrm{I}_{\mathrm{zz}} & =\mathrm{I}_{\mathrm{o}}+\mathrm{Ad}_{1} \\
& =213333,33+97593,76 \\
& =310927,09 \mathrm{~mm}^{4}
\end{aligned}
$$

Untuk rongga dalam $\left(\mathrm{I}_{\mathrm{o}}\right)$

$$
\begin{aligned}
\mathrm{I}_{\mathrm{o}}= & \frac{\mathrm{bh}^{3}}{12}=\frac{34(34)^{3}}{12} \\
= & 111361,33 \mathrm{~mm}^{4} \\
\mathrm{Ad}_{2} & =\mathrm{A}_{2} \times\left(\mathrm{y}_{2}-\mathrm{C}\right)^{2} \\
& =1156 \times(17-27,81)^{2} \\
& =1156 \times 116,87 \\
& =135085,65 \mathrm{~mm}^{4} \\
\mathrm{I}_{\mathrm{zz}} & =\mathrm{I}_{\mathrm{o}}+\mathrm{Ad}_{2} \\
& =111361,33+135085,65 \\
& =246446,98 \mathrm{~mm}^{4}
\end{aligned}
$$

Jadi inersia besi hollow dapat dicari dengan persamaan berikut:

$$
\begin{aligned}
\left(\mathrm{I}_{\mathrm{zz}}\right) & =\left(\mathrm{I}_{\mathrm{zz}} \text { keseluruhan }-\mathrm{I}_{\mathrm{zz}} \text { rongga }\right) \\
& =310927,09-246446,98 \mathrm{~mm}^{4} \\
& =64480,02 \mathrm{~mm}^{4}
\end{aligned}
$$

Jenis material yang digunakan pada dudukan penyangga pipa yaitu besi hollow 40x40x3.

Diketahui :

$$
\begin{aligned}
& \sigma \quad=370 \mathrm{~N} / \mathrm{mm}^{2} \\
& \sigma_{Y \mathrm{p}}=250 \mathrm{~N} / \mathrm{mm}^{2} \\
& \mathrm{Sf}_{1}=5,6 \text { (untuk bahan SF) } \\
& =6 \text { (untuk bahan S-C) }
\end{aligned}
$$

$\mathrm{Sf}_{2}=1,0$ (beban di kenakan secara halus)

$=1,0-1,5$ (beban sedikit tumbukan)

= 1,5-3,0 (beban dengan tumbukan besar).

Tegangan lentur yang diijinkan

$$
\begin{aligned}
\sigma_{\mathrm{ijin}} & =\frac{\sigma}{s_{f 2}} \\
& =\frac{370}{1,5} \mathrm{~N} / \mathrm{mm}^{2} \\
& =246,67 \mathrm{~N} / \mathrm{mm}^{2}
\end{aligned}
$$

Tegangan lentur yang diakibatkan beban

$$
\begin{aligned}
\sigma_{\text {beban }} & =\frac{M_{\text {maks }}}{I} \times C \\
& =\frac{60000 \mathrm{~N} \cdot \mathrm{mm}}{64480,02 \mathrm{~mm}^{4}} \times 27,81 \mathrm{~mm} \\
& =25,88 \mathrm{~N} / \mathrm{mm}^{2} \\
\sigma_{\text {beban }}< & \sigma_{\text {ijin }} \text { maka tegangan lentur aman }
\end{aligned}
$$

Tegangan geser yang diijinkan

$$
\begin{aligned}
\tau_{\mathrm{ijin}} & =\frac{\sigma}{s_{f 1} \times s_{f 2}} \\
& =\frac{370 \mathrm{~N} / \mathrm{mm}^{2}}{5,6 \times 1,5} \\
& =99,11 \mathrm{~N} / \mathrm{mm}^{2}
\end{aligned}
$$

Tegangan geser yang diakibatkan beban

$$
\begin{aligned}
\begin{aligned}
\tau_{\text {beban }} & =\frac{\mathrm{V}_{\text {maks }}}{\mathrm{A}} \\
& =\frac{200 \mathrm{~N}}{444 \mathrm{~mm}^{2}} \\
& =0,45 \mathrm{~N} / \mathrm{mm}^{2}
\end{aligned} \\
\begin{aligned}
& \tau_{\text {beban }}<\tau_{\mathrm{ijin}} \text { maka tegangan geser aman, Sehingga besi } \\
& \text { hollow } 40 \mathrm{x} 40 \mathrm{x} 3 \text { dapat digunakan karena tegangan lentur } \\
& \text { dan tegangan gesernya aman. }
\end{aligned}
\end{aligned}
$$

\subsection{Perhitungan estimasi waktu proses pemotongan.}

Waktu proses pemotongan dilakukan secara manual (stopwatch). Perhitungan waktu per satuan luas dimana besi hollow yang digunakan berdimensi $40 \mathrm{~mm}$ x $40 \mathrm{~mm}$ x $3 \mathrm{~mm}$, waktu percobaan pemotongan pertama $\left(\mathrm{t}_{1}\right)=104$ detik, percobaan pemotongan kedua $\left(\mathrm{t}_{2}\right)=110$ detik, dan percobaan pemotongan ketiga $\left(t_{3}\right)=101$ detik, Sehingga perhitungan waktu per satuan luas dapat dihitung dengan persamaan berikut:

$T=\frac{T_{\text {rata }} \text { rata }}{A} \quad:$

Dimana:

$$
\begin{array}{ll}
\mathrm{T} & =\text { Waktu per satuan luas }\left(\operatorname{detik} / \mathrm{cm}^{2}\right) \\
\mathrm{T}_{\text {rata-rata }} & =\text { Waktu rata-rata (detik) } \\
\mathrm{A} & \text { = Luas penampang potong }\left(\mathrm{cm}^{2}\right)
\end{array}
$$

a. Perhitungan waktu rata-rata

Diketahui :

Sehingga perhitungan waktu rata-rata adalah :

$\mathrm{T}_{\text {rata-rata }}=\frac{T 1+T 2+T 3}{n}$ 


$$
\begin{aligned}
\mathrm{T}_{\text {rata-rata }} & =\frac{104+110+101}{3} \\
\mathrm{~T}_{\text {rata-rata }} & =105 \text { detik }
\end{aligned}
$$

b. Perhitungan luas penampang potong

Diketahui :

Tinggi besi hollow $(P)=40 \mathrm{~mm}$

Tebal besi hollow $(l)=3 \mathrm{~mm}$

Lebar besi hollow $(p)=P-l=37 \mathrm{~mm}$

Sehingga perhitungan waktu rata-rata dapat dihitung dengan persamaan berikut :

$\mathrm{A}=(\mathrm{P} \times \mathrm{l})+(\mathrm{p} \times \mathrm{l})$

$A=(40 \mathrm{~mm} \times 3 \mathrm{~mm})+(37 \mathrm{~mm} \times 3 \mathrm{~mm})$

$\mathrm{A}=120+111$

$\mathrm{A}=231 \mathrm{~mm}^{2}$

$\mathrm{A}=23,1 \mathrm{~cm}^{2}$

Sehingga perhitungan waktu per satuan luas dapat dihitung dengan persamaan berikut:

$T=\frac{T_{\text {rata }- \text { rata }}}{A}$

$=\frac{105}{23,1}=4,54 \mathrm{dtk} / \mathrm{cm}^{2}$.

Dengan waktu per satuan luas $(\mathrm{T})=4,54 \mathrm{detik} / \mathrm{cm}^{2}$, Luas Penampang potong $(\mathrm{A})=23,1 \mathrm{~cm}^{2}$, dan jumlah benda $(\mathrm{I})=24$. Jadi untuk menghitung waktu total pemotongan dapat menggunakan persamaan sebagai berikut:

$T c=T \times A \times I$

Dimana :

Tc $=$ Waktu total pemotongan (menit)

$\mathrm{T}=$ Waktu per satuan luas $\left(\operatorname{detik} / \mathrm{cm}^{2}\right)$

A $\quad=$ Luas penampang potong $\left(\mathrm{cm}^{2}\right)$

I = Jumlah benda

Jadi waktu total pemotongan dapat dicari dari persamaan

$T c=T \times A \times I=\mathrm{T} \times \mathrm{A} \times \mathrm{I}$

$4 \times 23,1 \times 24=516,98$ detik $=41,95$ menit

Berikut ini merupakan rumus perhitungan gurdi yang akan digunakan pada rangka mesin plasma cutting:

Diketahui:

Material mild steel

$\mathrm{d}=12 \mathrm{~mm}$

$\mathrm{kr}=118^{\circ} / 2=59^{0}$

$\mathrm{V}=9,15-24,40 \mathrm{~m} /$ menit, $\mathrm{z}=2$

$1_{\mathrm{v}}=20 \mathrm{~mm}$

$1_{\mathrm{w}}=1 \mathrm{~mm}$

Sehingga perhitungan gurdi dapat dihitung dengan persamaan sebagai berikut. a. Perhitungan kecepatan putaran spindle (Taufiq Rochim, 1993)

$v=\frac{\pi \cdot d \cdot n}{1000}$

Dimana :

$v=$ kecepatan potong $(\mathrm{m} / \mathrm{menit})$

$n=$ putaran spindel (rpm)

$d=$ diameter gurdi (mm)

Sehingga perhitungan kecepatan potong dapat dihitung dengan persamaan sebagai berikut.

$v=\frac{\pi \cdot d \cdot n}{1000}$

$24,40=\frac{3,14 \cdot 12 \cdot n}{1000}$

$24400=37,68 n$

$n \quad=647,56 \mathrm{rpm} \approx 660 \mathrm{rpm}$

Jadi kecepatan putaran spindel yang diambil adalah sebesar $660 \mathrm{rpm}$

b. Perhitungan gerak makan per mata potong

$f s=\frac{V f}{z \times n}$

$F s$ bisa juga dicari dengan rumus $f s=0,084 \times \sqrt[3]{\mathrm{d}}$

Dimana :

$f s=$ gerak makan per mata potong $(\mathrm{mm} /$ putaran$)$

$V_{f}=$ kecepatan makan $(\mathrm{mm} / \mathrm{menit})$

$n=$ putaran spindle $(\mathrm{rpm})$

$z=$ jumlah gigi (mata potong)

Sehingga perhitungan gerak makan per mata potong dapat dihitung dengan persamaan sebagai berikut.

$f_{S}=0,084 \times \sqrt[3]{12}=0,084 \times 2,29$

$f s=0,192 \mathrm{~mm} /$ putaran

Sehingga kecepatan makan dapat dicari dengan persamaan berikut:

$f s=\frac{V f}{z \times n}$

$0,192=\frac{V f}{2 \times 660}$

$V f=0,192 \times 1320$

$V f=253,44 \mathrm{~mm} /$ menit

c. Perhitungan waktu pemotongan:

$t_{c}=\frac{I_{t}}{V_{f}}$

dimana :

$\mathrm{t}_{\mathrm{c}}=$ waktu pemotongan (menit)

$\mathrm{v}_{\mathrm{f}}=\operatorname{kecepatan}$ makan $(\mathrm{mm} / \mathrm{menit})$

$1_{\mathrm{t}}=$ panjang pemesinan $(\mathrm{mm})$

$=1_{\mathrm{v}}+1_{\mathrm{w}}+1_{\mathrm{n}}$

$1_{\mathrm{v}}=$ panjang langkah awal pemotongan

$1_{\mathrm{w}}=$ panjang pemotongan benda kerja

$\mathrm{l}_{\mathrm{n}}=$ panjang langkah akhir pemotongan

$1_{\mathrm{n}}=\left(\frac{\left(\frac{d}{2}\right)}{\tan k r}\right)$;

$\mathrm{k}_{\mathrm{r}}=$ sudut potong utama

$=1 / 2$ sudut ujung 
Sehingga perhitungan waktu pemotongan dapat dihitung dengan persamaan sebagai berikut:

$t_{c}=\frac{I_{t}}{V_{f}}=\frac{l_{v}+l_{w}+l_{n}}{V_{f}}=\frac{20+6+\left(\frac{\left(\frac{d}{2}\right)}{\tan k r}\right)}{253,44}$

$t_{c}=\frac{20+6+\left(\frac{\left(\frac{12}{2}\right)}{\tan 59^{\circ}}\right)}{253,44}$

$t_{c}=\frac{20+6+3,61}{253,44}=0,117$ menit,

karena pada rangka plasma cutting bagian terdapat 6 lubang maka waktu proses gurdi

$=$ Jumlah lubang $\times t_{c}=6 \times 0,117$

$=0,702$ menit

Proses pengelasan pada komponen rangka plasma cutting menggunakan mesin las portable. Diketahui rangka plasma cutting dibuat menggunakan besi hollow $40 \times 40 \times 3 \mathrm{~mm}$, panjang las per batang elektroda $=112$ $\mathrm{mm} /$ batang, dan waktu las per batang elektroda $=2,5$ menit/batang. Sehingga waktu pengelasan rangka atas dapat dihitung dengan persamaan berikut:

Menghitung panjang pengelasan total

$=$ Jumlah titik pengelasan $\mathrm{x}$ panjang pengelasan tiap titik $=144 \times 40 \mathrm{~mm}=5760 \mathrm{~mm}$

Dari data diatas, maka waktu pengelasan dapat dihitung menggunakan persamaan sebagai berikut.

a. Jumlah elektroda

Jumlah elektroda

$$
\begin{aligned}
& =\frac{\text { total panjang las }}{\text { panjang las per batang elektroda }} \\
& =\frac{5760}{112}=51,43 \approx 52 \text { batang }
\end{aligned}
$$

b. Waktu pengelasan

Waktu pengelasan $=$ Jumlah elektroda $\mathrm{x}$ waktu pengelasan perbatang elektroda

$$
=52 \times 2,5=130 \text { menit }
$$

Waktu perakitan merupakan waktu yang dibutuhkan untuk merakit suatu komponen menjadi alat yang berfungsi. Jadi, jumlah waktu yang dibutuhkan untuk proses perakitan adalah 280 menit $\approx 3,67$ jam. Proses finishing merupakan tahap akhir dari pembuatan alat/mesin. Jadi, jumlah waktu yang dibutuhkan untuk proses finishing adalah 415 menit $\approx 6,92$ jam. Setelah melakukan perhitungan proses produksi maka estimasi total waktu produksi bisa dicari dengan cara sebagai berikut:

Total waktu produksi $=$ waktu pemotongan + waktu gurdi + waktu pengelasan + waktu perakitan + waktu finishing $=1,29 \mathrm{jam}+0,645 \mathrm{jam}+2,8 \mathrm{jam}+3,67 \mathrm{jam}$ $+6,92$ jam $=15,325$ jam $\approx 2$ hari $(1$ hari $=8$ jam $)$, jadi estimasi waktu yang dihabiskan dalam pembuatan rangka plasma cutting adalah selama 15, 325 jam atau sama dengan 2 hari kerja jika dalam satu hari dikerjakan selama 8 jam.

\subsection{Penyelesaian}

Penyelesaian merupakan proses akhir dalam metode perancangan yang berisi proses pembuatan alat dan pengujian alat. Proses ini dilakukan setelah desain wujud dan perhitungan terselesaikan. Pada gambar 8 adalah hasil produk mesin plasma cutting. Hasil pengujian dapat dilihat pada tabel 3. Kesimpulan dari hasil uji plasma cutting, bahwa hasil potongan terbaik pada pipa dengan ketebalan $8 \mathrm{~mm}$ adalah pada putaran $10 \mathrm{rpm}$. Visualisasi hasil pemotongan dapat dilihat pada Tabel. 4.

Hasil pemotongan pada $10 \mathrm{rpm}$ menunjukkan hasil potongan yang rapi dan tidak terbentuk alur potong yang berundak-undak. Hasil potong seperti pada gambar 9 dibawah ini adalah hasil potong yang tidak rapi karena menghasilkan alur potongan yang berundak. Hasil pemotongan dengan mesin ini juga bisa digunakan untuk memotong variasi dengan bentuk profil hallsaw, yang dimaksudkan untuk percobaan pengelasan sambungan pada pipa dengan posisi yang berbeda. Bentuk profil variasi potongan yang digunakan ditunjukan pada gambar 10.

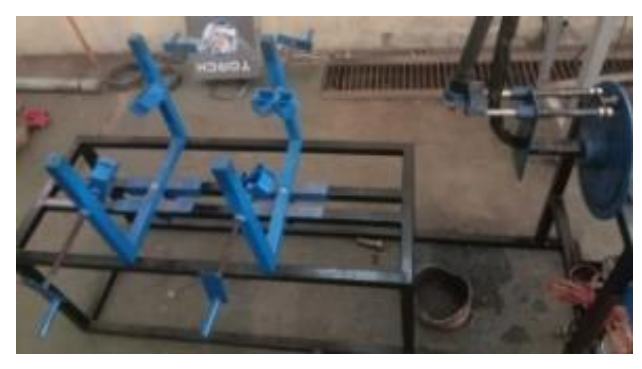

Gambar 8. Mesin plasma cutting

Tabel 3. Hasil uji mesin

\begin{tabular}{lccc}
\hline No & $\begin{array}{c}\text { Putaran } \\
(\mathbf{r p m})\end{array}$ & $\begin{array}{c}\text { Tebal } \\
(\mathbf{m m})\end{array}$ & Visualisasi \\
\hline 1 & 10 & \\
2 & 15 & 8 \\
3 & 20 & \\
\end{tabular}




\section{Tabel 4. Visualisasi hasil pemotongan}

\begin{tabular}{|c|c|c|c|}
\hline No. & rpm & $\mathbf{T}(\mathrm{mm})$ & Visualisasi \\
\hline 1. & 10 & & \\
\hline 2. & 15 & 8 & \\
\hline 3. & 20 & & \\
\hline
\end{tabular}

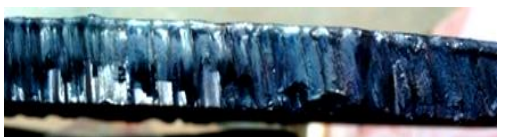

Gambar 9. Alur Potong Berundak

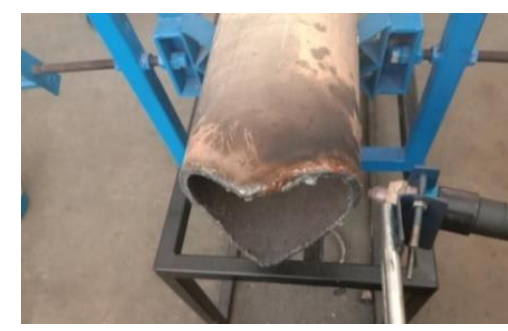

Gambar 10. Variasi bentuk potongan

Hasil potongan dilakukan pada kecepatan $10 \mathrm{rpm}$, sehingga dihasilkan alur potong yang rapi. Profil ini biasanya akan digunakan untuk konstruksi pipa yang disambung dengan pipa lain dengan proses pengelasan,

\section{Kesimpulan}

Dari hasil rancang bangun mesin pemotong pipa menggunakan plasma cutting didapatkan kesimpulan bahwa desain wujud dan desain detail rangka dengan dimensi 1500 x 400 x $600 \mathrm{~mm}$, meliputi bagian 2 rangka bawah dengan ukuran $1500 \mathrm{~mm}, 2$ rangka atas dengan ukuran $1000 \mathrm{~mm}, 5$ rangka bawah dengan ukuran 400 $\mathrm{mm}$. Serta ragum dengan dimensi $400 \times 400 \times 400 \mathrm{~mm}$, meliputi 4 rangka samping ragum dengan ukuran 400 $\mathrm{mm}, 2$ rangka bawah ragum $400 \mathrm{~mm}$. Hasil perhitungan mekanika teknik, material yang digunakan pada rangka mesin pemotong pipa menggunakan plasma cutting adalah besi hollow 40 x 40 x $3 \mathrm{~mm}$. Estimasi waktu produksi rangka mesin pemotong pipa menggunakan plasma cutting adalah 15,32 jam atau sama dengan 2 hari kerja jika dalam satu hari dikerjakan selama 8 jam.

Bill Of Material (BOM) untuk pembuatan mesin menghabiskan 53 part. Rangka mesin pemotong pipa menggunakan plasma cutting dapat berfungsi dengan baik. Hasil pemotongan terbaik dihasilkan pada pemotongan plat tebal $8 \mathrm{~mm}$ dengan kecepatan putaran mesin10 rpm. Pada kabel plasma cutting perlu ditambahkan sistem pelindung kabel yang berfungsi agar kabel las tidak terkena panas saat pemotongan berlangsung.

\section{Daftar Pustaka}

[1] Sularso and K. Suga, Dasar Perencanaan Dan Pemilihan Elemen Mesin. Jakarta: Pradnya Paramita, 1997.

[2] E. . Popov and A. Zainul, Mekanika Teknik. Jakarta: Penerbit Erlangga, 1995.

[3] P. Pujono and H. P. Menang, "Perancangan Mesin Potong Las Lingkar Semi Otomatis Dengan Ketebalan Material Potong 3 - 8 mm," Bangun Rekaprima Maj. Ilm. Pengemb. Rekayasa, Sos. dan Hum., vol. 3, no. 2, Oktober, pp. 9-14, Oct. 2017, doi: 10.32497/BANGUNREKAPRIMA.V3I2, OKTOBER.862.

[4] S. Siregar and A. Sukandar, "Perancangan Rangka Mesin Penggiling Adonan Pangsit Kapasitas 80 Kg," 259, vol. 94, 2011.

[5] E. Sutikno, "Analisis Tegangan Akibat Pembebanan Statis pada Desain Carbody Tec Railbus dengan Metode Elemen Hingga," Rekayasa Mesin, vol. 2, no. 1, pp. 65-81, 2011.

[6] A. R. Kistanto, B. Liputo, and F. Darise, "Desain Sistem Mekanik Plasma Cutter Menggunakan Prinsip Run Stabilizer Process," J. Teknol. Pertan. Gorontalo, vol. 3, no. 1, pp. 29-29, May 2018, doi: 10.30869/JTPG.V3I1.167.

[7] A. Ruswandi, Metode Perancangan. Bandung: Politeknik Manufaktur Negeri Bandung (POLMAN), 2004.

[8] T. Rochim, Klasifikasi Proses Pemesinan. Bandung: ITB Bandung, 1993. 